\title{
Reactivation of an Idle Lease to Increase Heavy Oil Recovery Through Application of Conventional Steam Drive Technology in a Low Dip Slope and Basin Reservoir in the Midway-Sunset Field, San Jaoquin Basin, California
}

\author{
Quarterly Report \\ January 1 - March 31, 1997
}

\author{
By: \\ Steven Schamel
}

Work Performed Under Contract No.: DE-FC22-95BC14937

\author{
For \\ U.S. Department of Energy \\ Office of Fossil Energy \\ Federal Energy Technology Center \\ P.O. Box 880 \\ Morgantown, West Virginia 26507-0880
}

By

Energy \& Geoscience Institute at The University of Utah

423 Wakara Way

Salt Lake City, Utah 84108 


\section{Disclaimer}

This report was prepared as an account of work sponsored by an agency of the United States Government. Neither the United States Government nor any agency thereof, nor any of their employees, makes any warranty, express or implied, or assumes any legal liability or responsibility for the accuracy, completeness, or usefulness of any information, apparatus, product, or process disclosed, or represents that its use would not infringe privately owned rights. Reference herein to any specific commercial product, process, or service by trade

name, trademark, manufacturer, or otherwise does not necessarily constitute or imply its endorsement, recommendation, or favoring by the United States Government or any agency thereof. The views and opinions of authors expressed herein do not necessarily state or reflect those of the United States Government or any agency thereof. 


\section{TITLE: REACTIVATION OF AN IDLE LEASE TO INCREASE HEAVY OIL RECOVERY THROUGH APPLICATION OF CONVENTIONAL STEAM DRIVE TECHNOLOGY IN A LOW DIP SLOPE AND BASIN RESERVOIR IN THE MIDWAY-SUNSET FIELD, SAN JAOQUIN BASIN, CALIFORNIA}

Cooperative Agreement No.: DE-FC22-95BC14937

Contractor Name and Address: Energy \& Geoscience Institute at the University of Utah, 423 Wakara Way, Salt Lake City, UT 84108

Date of Report: July 29, 1997

Award Date: June 14, 1995

Anticipated Completion Date: March 13, 2000

Government Award for Current Budget Period: \$1,531,520.00

Principal Investigator: Steven Schamel

Project Manager: Jerry Castille, National Petroleum Technology Office

Reporting Period: January 1- March 31, 1997

\section{Objective}

This project reactivates ARCO's idle Pru Fee property in the Midway-Sunset field, California and conducts a continuous steamflood enhanced oil recovery demonstration aided by an integration of modern reservoir characterization and simulation methods. Cyclic steaming was used to reestablish baseline production within the reservoir characterization phase of the project. During the demonstration phase begun in January 1997, a continuous steamflood enhanced oil recovery was initiated to test the incremental value of this method as an alternative to cyclic steaming. Other economically marginal Class III reservoirs having similar producibility problems will benefit from insight gained in this project. The objectives of the project are: (1) to return the shut-in portion of the reservoir to optimal commercial production; (2) to accurately describe the reservoir and the recovery process; and (3) to convey the details of this activity to the domestic petroleum industry, especially to other producers in California, through an aggressive technology transfer program.

The 40 ac Pru Fee property is located in the super-giant Midway-Sunset field and produces from the late Miocene Monarch Sand, part of the Monterey Formation. The Midway-Sunset field was discovered prior to 1890. Cumulative production from the field through 1995 was 2.3 billion barrels of oil and 563 billion cubic feet of gas, with remaining reserves estimated to exceed $450 \mathrm{MMBO}$. The average daily field production in 1995 was 
163,400 barrels of oil. In the Pru Fee property, now held by ARCO Western Energy, cyclic steaming was used to produce $13^{\circ}$ API oil. However, the previous operator was unable to develop profitably this marginal portion of the Midway-Sunset field using standard enhanced oil recovery technologies and chose rather to leave more than 3.0 MMBO of oil in the ground that otherwise might have been produced from the 40 ac property. Only $927 \mathrm{MBO}$ had been produced from the property when it was shut-in in 1987. This is less than $10 \%$ of the original oil-in-place, which is insignificant compared to typical heavy oil recoveries in the Midway-Sunset field of 40 to $70 \%$. The objective of the demonstration project is to encourage a similar incremental increase in production in all other marginal properties in the Midway-Sunset and adjacent fields in the southern San Jaoquin Basin.

A previously idle portion of the Midway-Sunset field, the ARCO Western Energy Pru Fee property, is being brought back into commercial production through tight integration of geologic characterization, geostatistical modeling, reservoir simulation, and petroleum engineering. This property, shut-in over a decade ago as economically marginal using conventional cyclic steaming methods, has a 200-300 foot thick oil column in the Monarch Sand. However, the sand lacks effective steam barriers and has a thick water-saturation zone above the oil-water contact. These factors require an innovative approach to steam flood production design that will balance optimal total oil production against economically viable steam-oil ratios and production rates. The methods used in the Class III demonstration are accessible to most operators in the Midway-Sunset field and could be used to revitalize properties with declining production of heavy oils throughout the region.

\section{Summary of Technical Progress}

\section{General Statement}

In January 1997 the project entered its second and main phase with the purpose of demonstrating whether steamflood can be a more effective mode of production of the heavy, viscous oils from the Monarch Sand reservoir than the more conventional cyclic steaming. The objective is not just to produce the pilot site within the Pru Fee property south of Taft (Figure 1), but to test which production parameters optimize total oil recovery at economically acceptable rates of production and production costs.

During the initial phase of the project a multifaceted feasibility study was carried out to examine whether the pilot project could be justified technically and economically at this site. This study included:

1. Recompletion of 9 shut-in wells and drilling of an additional producer and a new temperature observation well. A core was taken from the reservoir interval in the new producer, Pru-101. The wells were produced by conventional cyclic steaming over a period of 15 months to establish a production baseline for the site. 


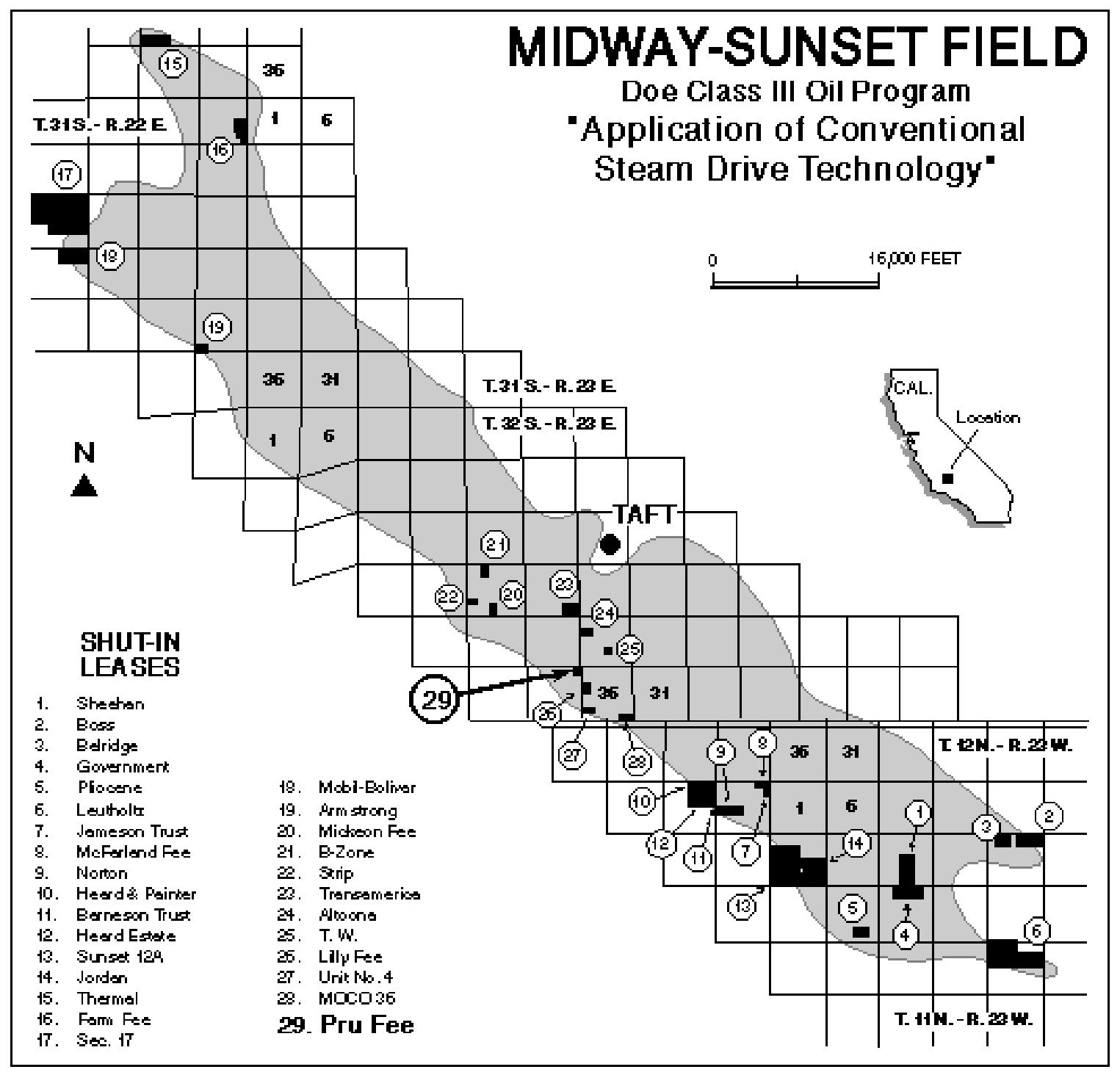

Figure 1: Location of the Pru Fee property south of Taft in the central Midway-Sunset field, southern San Joaquin Basin, California.

2. Characterization of the stratigraphy and petrophysical properties of the Monarch Sand reservoir using existing well logs and analyses on samples in the core taken from Pru-101. The resulting data were used to develop a geostatistical model of the reservoir at the Pru Fee property and a specific reservoir simulator for the pilot test site on the property.

3. Use of the reservoir simulator to test various steamflood and cyclic steaming production options leading to design of a production strategy for the pilot steamflood based on a four pattern, 9-spot array covering 8 ac near the center of the 40 ac Pru Fee property. The array chosen required drilling additional producers and injectors to supplement the existing wells recompleted in the initial phase of the project. 
The simulations run for the pilot site were very encouraging. Expected oil rate for the project are based on the 9-spot "no cycles" base case simulation results. The initial rate per new well is estimated at 10 BOPD, ramping up to 29 BOPD (320 BOPD total pilot) in 16 months, flat for 28 months, then declining at $40 \%$ harmonically to the economic limit. Steam rate is forecasted at 300 BSPD per injector constant for the life of the project. Total peak steam rate is $1200 \mathrm{BSPD}$ for the pilot. The gross capital investment of $\$ 1.9$ $\mathrm{MM}$ will produce $550 \mathrm{MBO}(\$ 2.89 / \mathrm{BO})$ with a PW10 of $\$ 1,177 \mathrm{M}$ and rate of return of $49 \%$, based on uninflated economics. Recoverable reserves are determined by the economic limit. However, gross expected recoverable reserves are $550 \mathrm{MBO}$ for the 8 ac pilot. Target additional recoverable oil reserves from the 40 ac property are $2.75 \mathrm{MMBO}$ or greater.

After several years of being shut-in, the existing producers on the Pru Fee property are in reasonable mechanical condition and can, therefore, be utilized as viable producers. Production response to cyclic steam is very encouraging in the new producer. However, productivity in the old producers appears to be limited in comparison. It is realized from the initial baseline cyclic production tests and temperature monitoring that effectively heating the entire reservoir will be the key challenge in economically developing the Pru property.

Early production results following the second steam cycle are encouraging. Some old wells, such as producer D-1 (refer to Figure 2), responded better to the second steam cycle. The old wells may have a high near-wellbore skin, as compared to a new well. Time will tell whether this trend of improved production will continue. If it does, this may indicate that the old, abandoned wells may still have the potential to be economic producers as the reservoir heats up with onset of the steamflood.

\section{Activities at the Pru Fee pilot site}

Activities on the pilot site during the first quarter of 1997 included drilling 18 new wells - 11 producers (Pru-201 through Pru-211), 4 injectors (Pru 12-1 through Pru 12-4), and three temperature observation wells (TO-2 through TO-4). The drilling was started on January 14 and completed on March 16. All wells were logged. The locations of the new wells on the Pru Fee property are shown in Figure 2. The four pattern, 9-spot array utilizes 10 pre-existing wells that were recompleted and cyclic steamed in the initial phase of the project. All new wells were drilled into the oil-water contact to establish the depth of that horizon, then plugged to $30 \mathrm{ft}$ above the OWC. 


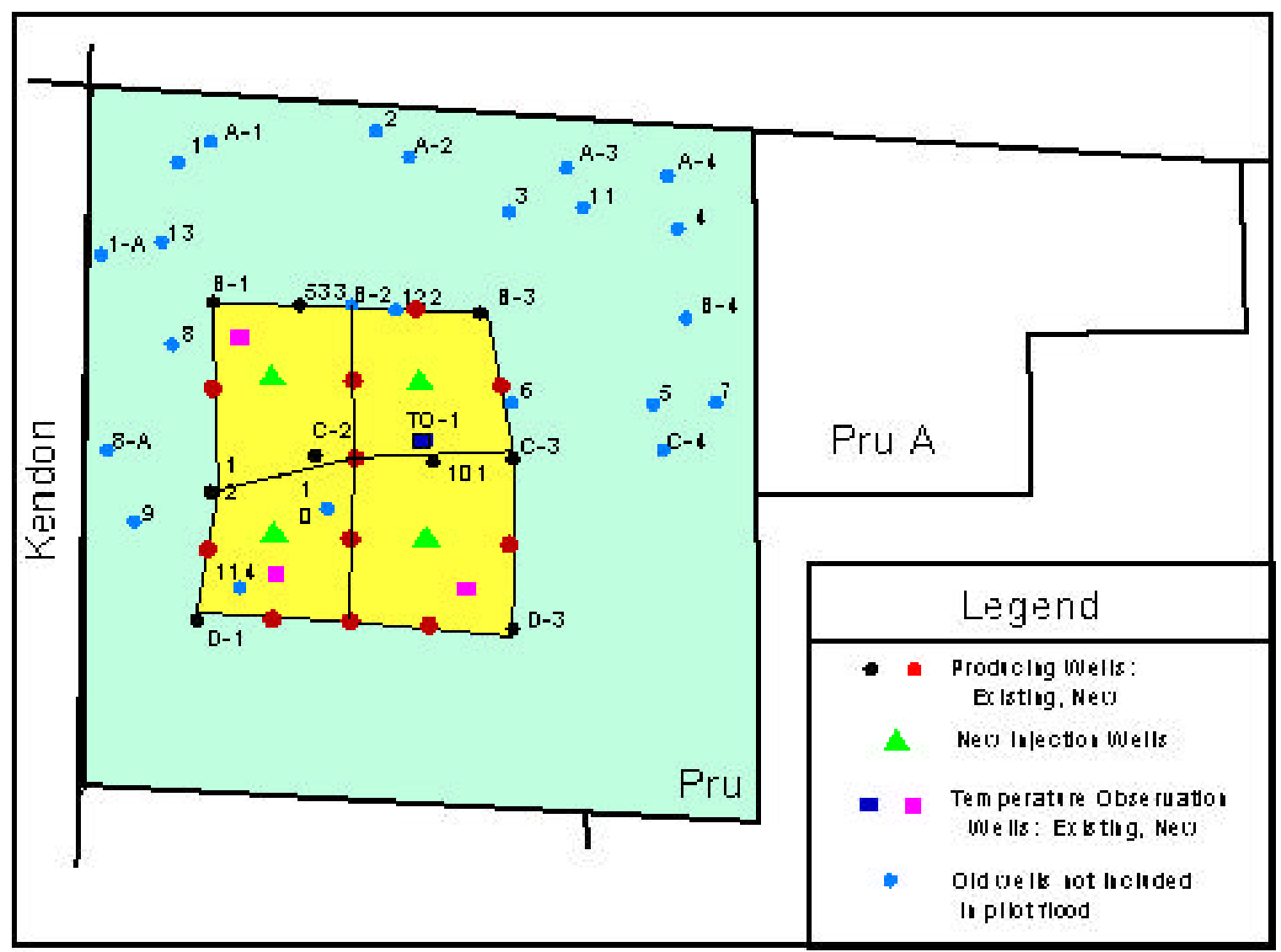

Figure 2: Location of wells within the Pru Fee property. Highlighted is the four pattern 9-spot steamflood array forming the pilot demonstration.

All wells were open hole logged with Schlumberger's Platform Express logging suite, including SP, gamma ray, caliper, contact temperature, density, neutron, and AIT resistivity. The injectors and temperature observation wells also were cased hole logged with contact temperature following completion to establish a baseline static reservoir temperature profile.

The producers were completed with 7" casing cemented to the top of the Monarch, or just below the base of depletion, if any. The open hole was then underreamed to 13" through the Monarch to bottom of the well. A slotted liner with 0.040" slots was placed through the Monarch, with the bottom slot 30' above the OWC and blank pipe from that point down to TD. This allows the pump to be placed as low in the well as possible to maximize reservoir drawdown. The wells were gravel packed with 8-12 $\mathrm{M}$ gravel to minimize formation sand entry.

Three whole cores were obtained in the Tulare formation in well Pru 209. The cores were cut at depths of 527' - 556', 782' - 812' and 972' - 1001', with $100 \%$ core recovery. 
The first well, Pru 201, was placed on production on February 13. By March 29 all of the wells in the four pattern array were on production. Pre-steam production rates are typically 0 to 1 BOPD per well. However, following an initial cyclic steaming of about 10,000 barrels of steam (cold water equivalent), the rate per well increased to 10-20 BOPD.

Evaluation of perforation depths for the injector completions was started. The plan is to perforate each injector with six 0.25 " diameter holes to limit steam entry into each portion of the reservoir to the target injection rate. Standoff from the oil-water contact is to be maintained according to the reservoir simulation results from the reservoir characterization phase which indicated that the lowest injection point should be no less than 70' above the OWC.

\section{Technology Transfer}

By invitation, the results of the initial phase of the project were presented in a poster at the Fourth International Reservoir Characterization Technical Conference held in Houston, Texas on March 2-4, 1997. The conference was organized jointly by the U.S. Department of Energy and the American Association of Petroleum Geologists. A paper "Reactivation of an idle lease to increase heavy oil recovery through application of conventional steam drive technology in the Midway-Sunset Field, San Joaquin Basin, California" was published in a proceedings volume for the conference. 